\title{
A RAPID METHOD FOR THE ESTIMATION OF CAERULOPLASMIN LEVELS IN HUMAN SERUM, THE ESTABLISHMENT OF THE CLINICAL NORM AND THE STUDIES" OF THE CAERULOPLASMIN LEVELS IN VARIOUS CONDITIONS
}

\author{
S. SENTHESHANMUGANATHAN, D. DHARMADASA*, \\ S. WIJERATNE**, AND N. J. GAMMANPILA***. \\ Department of Biochemistry, Medical Research Institute, Colombo, Sri Lanka.
}

(Date of receipt : 15.11.85)

(Date of acceptance : 07.11.86)

\begin{abstract}
A rapid method was developed for the estimation of caeruloplasmin levels in human subjects and the reliability of the method established by carrying out optimal condition and routine condition variance tests. The caeruloplasmin levels in 94 Sri Lankans were investigated and the clinical norm established. The serum caeruloplasmin levels lie between the range $1.19-2.78 \mu \mathrm{moles} / 1$ (18-42 $\mathrm{mg} \%$ ) with the mean of $1.98 \mu$ moles $/ 1(29.95 \mathrm{mg} \%)$ and the standard deviation of $0.38 \mu \mathrm{moles} / 1$ (5.72 $\mathrm{mg} \%$ ). The caeruloplasmin levels were also investigated in persons suffering from liver diseases and in pregnant mothers. The values were raised in viral hepatitis, and in pregnancy but decreased in Wilson's disease and alcoholic cirrhosis.
\end{abstract}

\section{Introduction}

Copper is found in serum as metaloproteins. About $96 \%$ of the plasma copper is firmly bound to the $\alpha_{2}-$ globulin and known as caeruloplasmin. Most of the non-caeruloplasmin bound copper, is attached to the serum albumin. It is believed that copper performs catalytic functions in the living organism. Copper influences erythropoiesis and its deficiency impairs absorption and transport of iron and decreases haemoglobin synthesis.

Caeruloplasmin is estimated by several methods, ${ }^{1,2,3,4,5,6}$ but the best and the most convenient method is to measure the intensity of the purple coloured complex formed by the oxidation of para phenyl diamine (PPD) to give quinone types of compounds. This complex has a characteristic absorbance at $525 \mathrm{~nm}$ or $530 \mathrm{~nm}$. Henry $e$ et $a l^{5}$ recorded the optical density at 10 minutes and 40 minutes incubation at $37^{\circ} \mathrm{C}$, after the addition of serum. The difference between the two figures was a measure of the "Department of Biochemistry, General Hospital, Kurunegala, Sri Lanka.

* Department of Biochemistry, Colombo Soutb General Hospital, Kalubowila, Sri Lanka. *** Department of Biochemistry, Cancer Institute, Mabaragama, Sri Lanka. 
serum oxidase activity and normal sera produced a different optical density of 0.28 to 0.57 at $530 \mathrm{~nm}$. They used an empirical figure of 5000 to convert the optical density at $530 \mathrm{~nm}$ per minute at $25^{\circ} \mathrm{C}$, to $\mathrm{mg}$ caeruloplasmin per $100 \mathrm{ml}$ of serum. Conversion factor in this case became $5000 \mathrm{x}$ Tf $\times 1 / 30$ where Tf is the temperature correction. Houchin ${ }^{6}$ however, recorded the optical density at $525 \mathrm{~nm}$ after 15 minutes incubation at $37^{\circ} \mathrm{C}$ and reported the activity as difference in optical density or $\mathrm{mg}$ of caeruloplasmin per $100 \mathrm{ml}$, by means of the formula $150 \times \mathrm{OD}_{525} \quad 1.7$ where $\mathrm{OD}_{525}$ is optical density at $525 \mathrm{~nm}$. The conversion to international units was calculated as follows -

$\frac{\mathrm{mg} \% \times 10 \times 1000}{151,000}=$ Moles $/ 1$

151,000 is the molecular weight of caeruloplasmin.

This procedure cannot be adopted as a routine method in most Sri Lankan laboratories because of the non-availability of visible spectrophotometers. It was decided to estimate the colour intensity both colorimetrically and spectrophotometrically in order to correlate the findings between the two readings.

In the recent past, there have been very many requests for the estimation of caeruloplasmin levels in patients suffering from Wilson's disease. But no data is available on caeruloplasmin levels in Sri Lankans. This and the non-availability of a rapid method, prompted modification of the existing method using a colorimeter which could then be used in most provincial laboratories.

\section{Materials and Methods}

\subsection{Reagents}

Paraphenylene diamine dihydrochloride powder obtained from BDH Chemicals Ltd, was brown in colour because of its auto-oxidative properties. It was therefore recrystallized using ethanol and water. After recrystalisation it was a colourless compound having a melting point of $140^{\circ} \mathrm{C}$. It is necessary to store this compound in an amber coloured bottle in a dessicator to prevent oxidation.

Sodium azide (a white powder) was also obtained from BDH Chemicals Ltd.

The buffer used for the assay was a glacial acetic acid sodium acetate buffer of molarity $0.55 \mathrm{M}$ and $\mathrm{pH} 5.2$. $(20 \mathrm{ml}$ glacial acetic acid and $98.3 \mathrm{~g}$ anhydrous sodium acetate dissolved in 1 litre). The $\mathrm{pH}$ was checked by a $\mathrm{pH}$ 
meter, PYE UNICAM Model 291 mk 2.

To establish clinical norms, the blood samples from normal donors were obtained from the Blood Bank, General Hospital, Colombo. All samples were screened by the Blood Bank for haemoglobin, Wasserman reaction, total proteins and for malarial parasites.

\subsection{Pathological specimens}

Samples of blood received by the Biochemistry Department of the Medical Research Institute from several institutions in the country for routine assay for hepatitis, cirrhosis, Wilson's disease and other abnormalities, were used to estimate the caeruloplasmin levels. Samples of the blood from women in various stages of pregnancy were obtained from the Castle Street Hospital for Women, Borella.

\subsection{Quality Control Serum}

The pooled serum used for the estimation of optimal condition variance (OCV) and routine condition variance (RCV) was from samples of serum received for routine biochemical estimations. This serum was dispensed in $1 \mathrm{ml}$ portions, in sterile bottles and stored at $-20^{\circ} \mathrm{C}$.

\subsection{Assay of caeruloplasmin activity}

One $\mathrm{ml}$ of buffered substrate $(0.1 \% \mathrm{w} / \mathrm{v}$ paraphenylene diamine dihydrochloride in acetate buffer, freshly prepared) was pipetted into each of two tubes, test and blank, covered with liquid paraffin, and pre-incubated for $5 \mathrm{~min}$ to attain $37^{\circ} \mathrm{C}$, using a water bath. To the test, $0.1 \mathrm{ml}$ of serum was added and incubated for exactly 15 minutes more. Then $5 \mathrm{ml}$ of azide solution $(0.2 \% \mathrm{w} / \mathrm{v})$ was added both to the blank and to the test to inhibit the enzymic reaction and $0.1 \mathrm{ml}$ of serum added to the control and the purple colour was measured using Klett Summerson colorimeter with filter No.54 (green), and Corning -253 spectrophotometer at $525 \mathrm{~nm}$ against the blank as zero.

Total protein was determined by the Biuret method, ${ }^{7}$ albumin by the bromocresol green binding method, ${ }^{8}$ bilirubin by treatment with diazotised sulphanilic acid, 9 serum glutamate oxalocetate transaminase (SGOT) and serum glutamate pyruvate transaminase (SGPT) by the 2,4 dinitro phenyl hydrazine method ${ }^{10}$ and alkaline phosphatase by the antipyrine method. ${ }^{11}$ 


\section{Results and Discussion}

\subsection{Correlation between colorimetry and spectrophotometry}

The relationship between the colorimetric and spectrometric readings is shown in Figure 1. It was interesting to note that the colorimetric readings were found to be 500 times that of the spectrometric readings $(525 \mathrm{~nm})$. This was so in almost all the readings. Therefore the empirical formula of Houchin ${ }^{6}$ becomes $(0.3 \times$ colorimetric reading $)-1.7 \mathrm{mg}$ of caeruloplasmin per $100 \mathrm{ml}$ of serum.

\subsection{Quality control}

Before the introduction of any method of assay for routine use the WHO has recommended ${ }^{11}$ that optimal condition variance (OCV) should be determined by analysing 20 replicate speciments. The results of such analysis of the OCV, given in Figure 2, show that the variation did not exceed \pm 2 SD (standard deviation) of the mean. In this case the value of the SD was 0.099 $\mu$ moles/1 (1.49 $\mathrm{mg} \%)$. OCV was calculated by the equation SD/ $\bar{x} \times 100$ where $\mathrm{SD}$ is standard deviation and $\overline{\mathrm{x}}$ is the arithmetic mean. It gave a value of $4.76 \%$. OCV varies from estimation to estimation and the values of enzymes such as amylase, SGPT and Lactate dehydrogenase are $6,7 \& 8$ respectively. ${ }^{8}$ Therefore, the value $4.76 \%$ obtained by the present method seems satisfactory.

After OCV was established for the method, the routine condition variance (RCV) was also established over a period of 20 days, using the same sample under identical conditions. During RCV estimation, at least two random serum samples were included in each batch of assay. The RCV, shown in Figure 3, was $8.11 \%$ which seems satisfactory.

\subsection{Clinical Norms}

The clinical norm was established on 85 males and 9 females between the ages of 20 and 60 . The frequency of distribution of the caeruloplasmin levels in Sri Lanka is shown in the form of a histogram in Figure 4. The standard deviation was $0.379 \mu$ moles/1 (5.72 $\mathrm{mg} \%)$ and arithmetic mean was $1.98 \mu$ moles $/ 1(29.95 \mathrm{mg} \%)$ of serum. The lowest value was 1.20 $\mu$ moles/1 (18.1 mg\%) and the highest value $2.74 \mu$ moles/1 $(41.5 \mathrm{mg} \%)$ of serum. The normal range was from 1.19 to $2.78 \mu$ moles/1 (18 to $42 \mathrm{mg} \%$ ) of serum.

Statistical normality of the sampling was established by plotting the results on a normal probability paper, as shown in Figure 5. The resulting straight line confirmed the sampling as satisfactory and the results as 


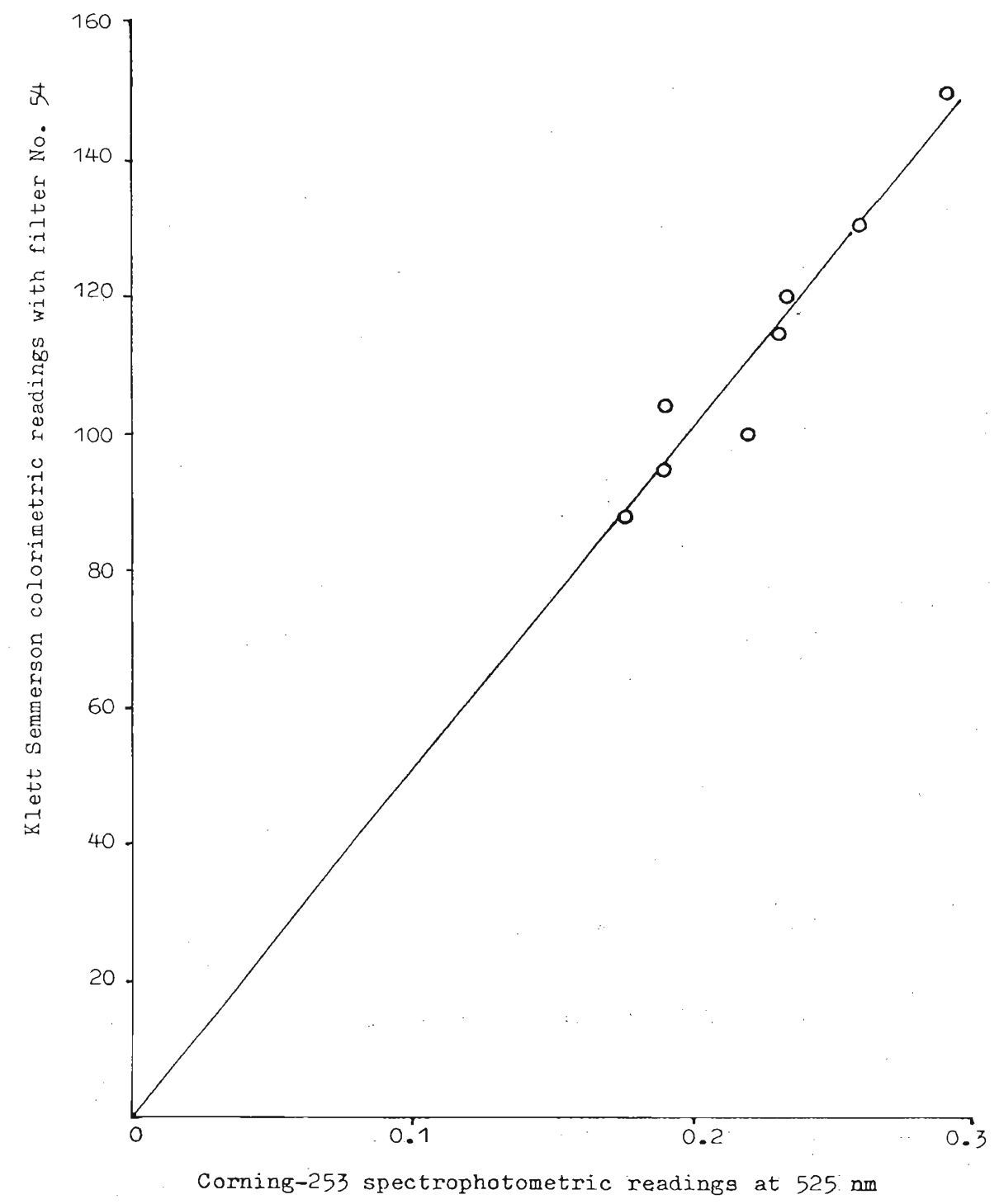

Figure 1. Relationship between colorimetric and spectrophotometric readings Caeruloplasmin was assayed as described under 2.5. The intensity of the colour was measured using Klett Summerson colorimeter with filter No.54 and spectrometric readings recorded on a Corning- 253 spectrometer against the blank at zero. 


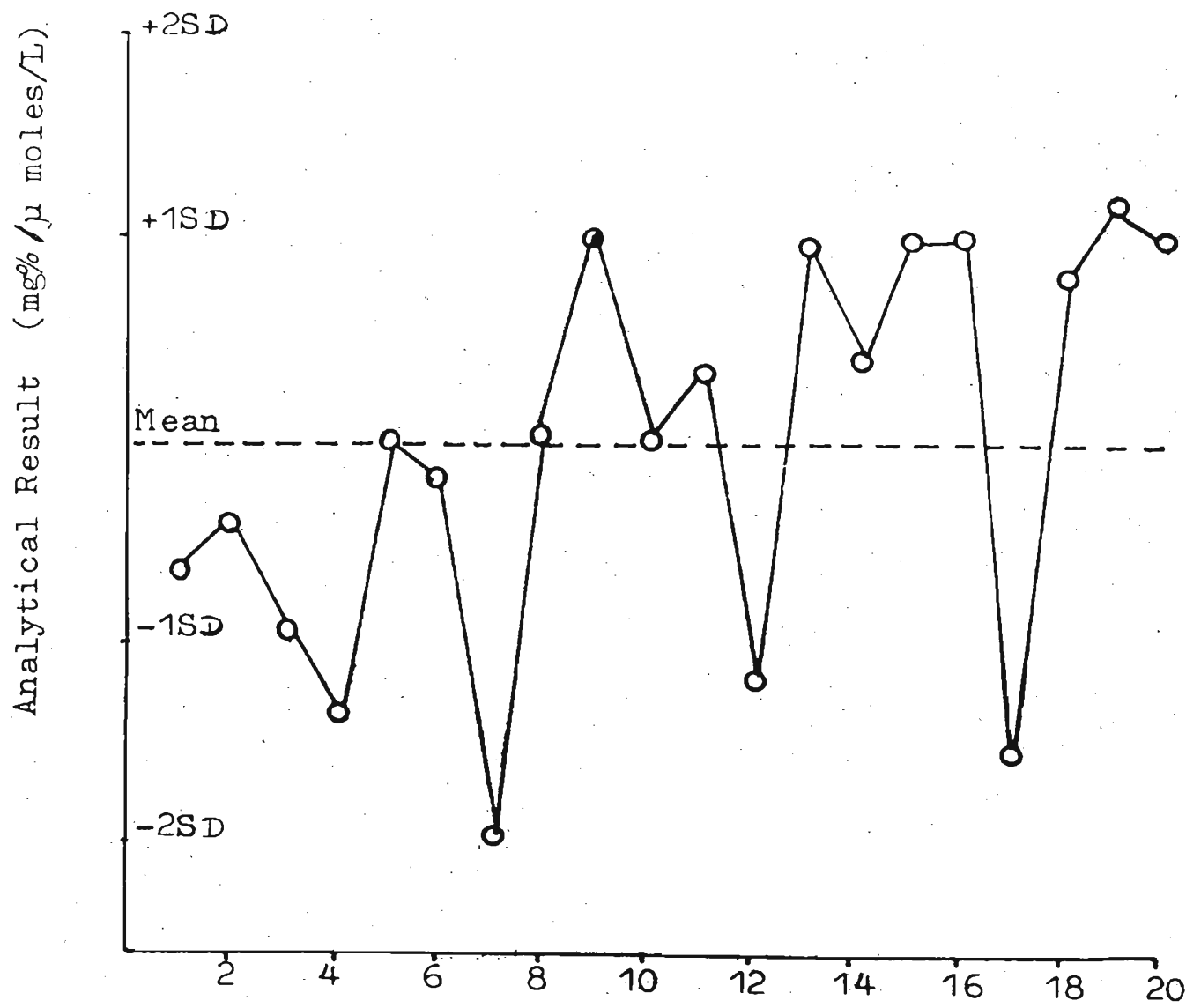

Analytical results in order of performances

Figure 2. Optimal condition variance for the assay of serum caeruloplasmin Caeruloplasmin was assayed as described under 2.5. Tests were carried out on pooled serum on 20 replicate specimens at the same time under optimal conditions. Colorimetric readings were recorded on a Klett Summerson using filter No. 54. SD = Standard deviation. 


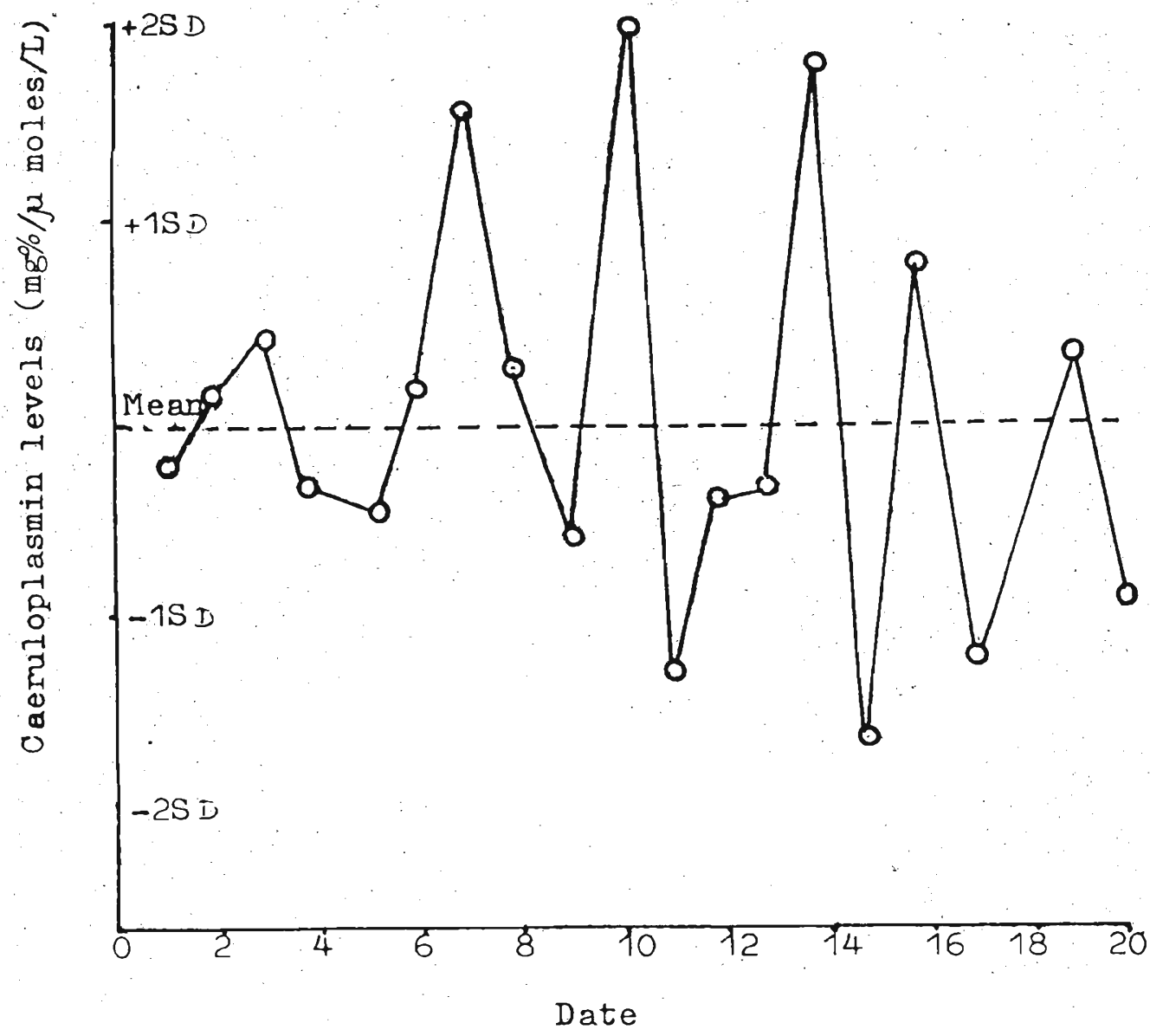

Figure 3. Routine condition variance for the assay of serum caeruloplasmin Caeruloplasmin was assayed as described under 2.5. Pooled serum, dispensed in sterilized bottles and stored at $-20^{\circ} \mathrm{C}$, was used in the assay. Colorimetric readings were recorded on a Klett Summerson using filter No. 54. $\mathrm{SD}=$ Standard Deviation . 


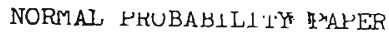

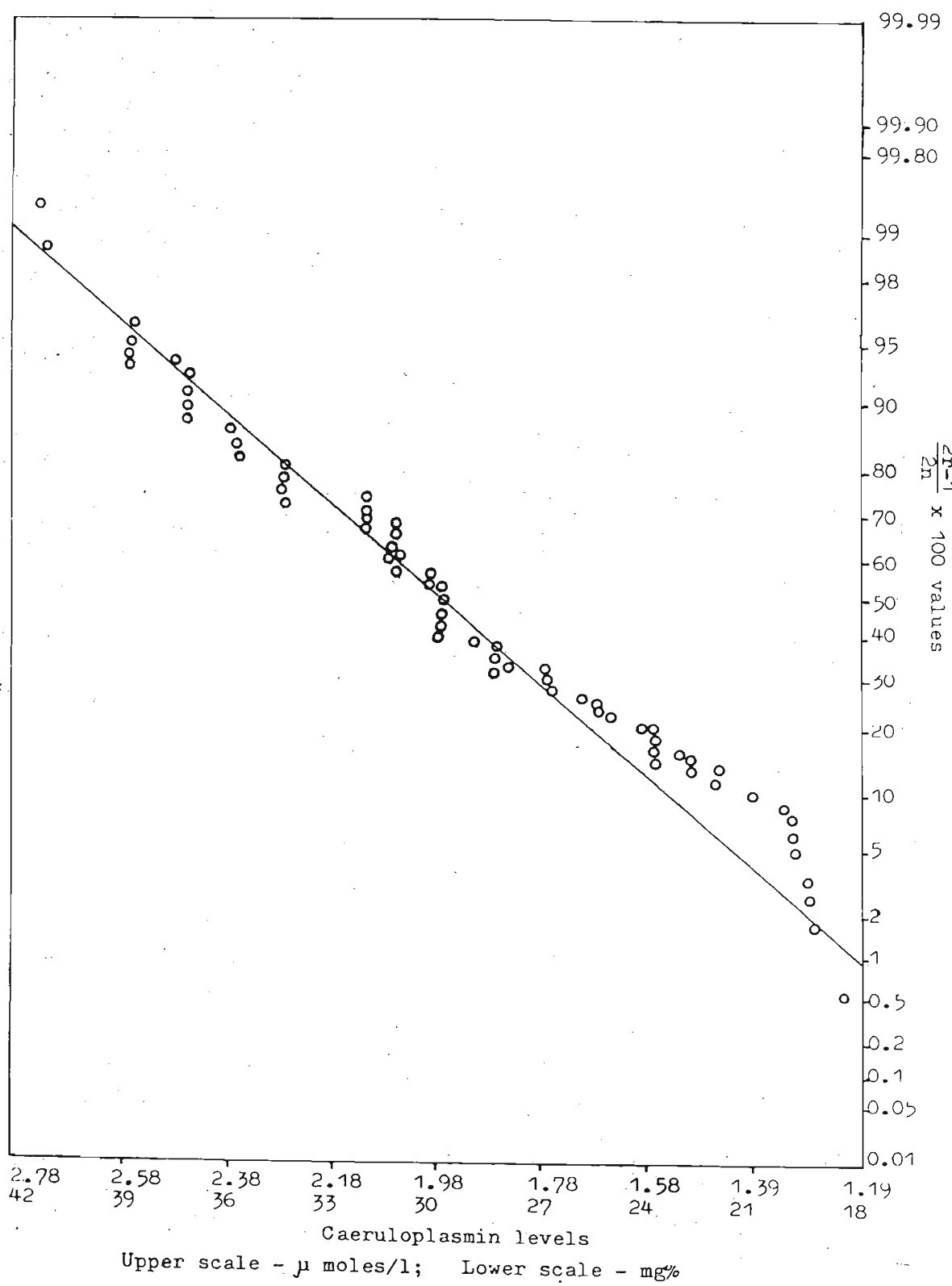

Figure 4. Distribution of caeruloplasmin activity in Sri Lankans

Caeruloplasmin was assayed as described under. 2.5. The intensity of the colour was measured using a Klett Summerson colorimeter, with filter No. 54 against the blank as zero. 


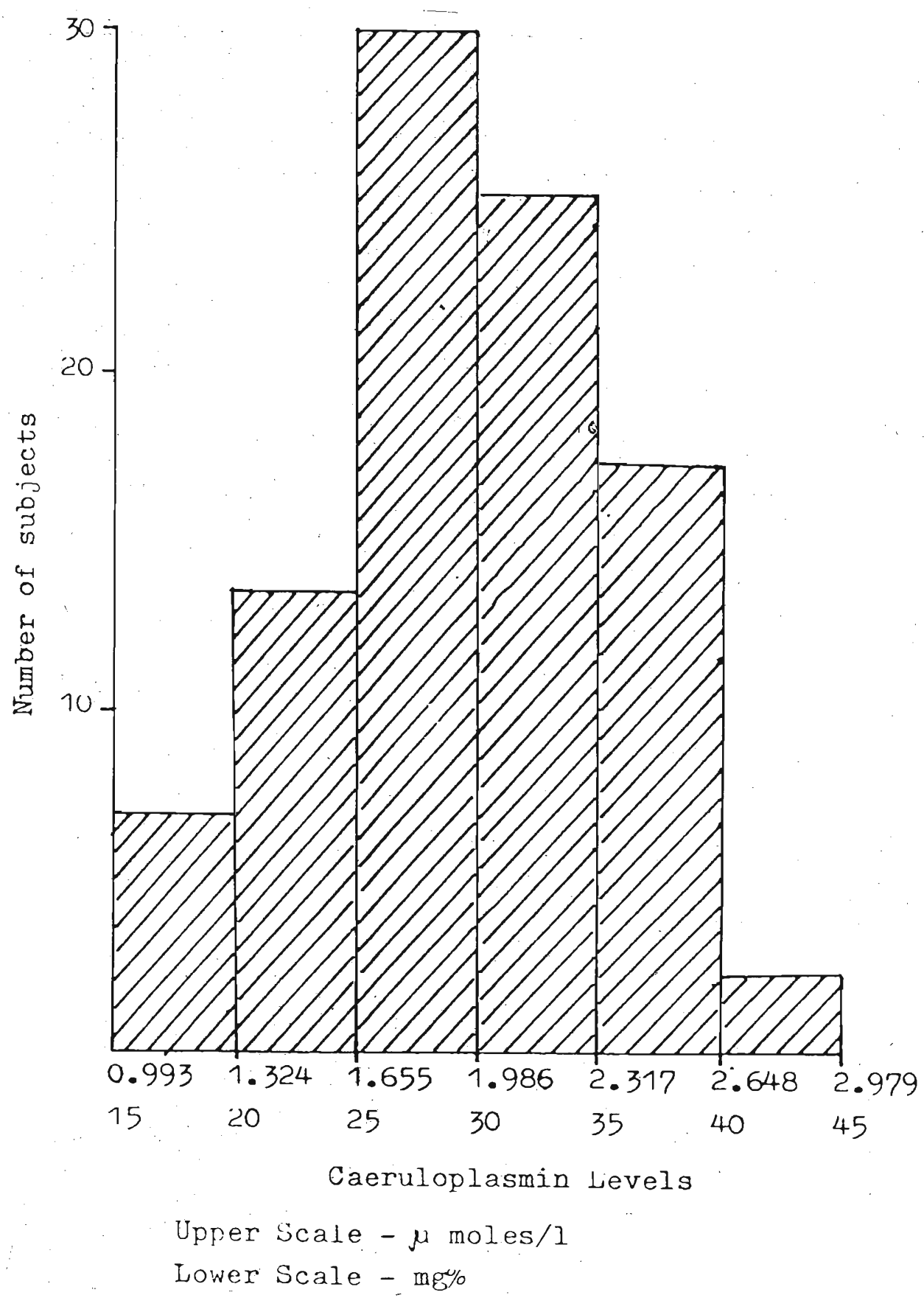

Figure 5. Normal probability distribution

Caeruloplasmin was determined'as described under. 2.5. $\frac{2 r-1}{2 \pi} \times 100$ was calculated where $n$ is the sample size (94) and $r$ is the number is ascending order of the values. The graph was plotted on a normal probability paper. $\frac{2 \mathrm{r}-1}{2 \mathrm{n}} \times 100$ figures on the vertical axis and caeruloplasmin levels on the $\mathrm{X}$ axis. 
statisticaliy acceptable.

The results (Table 1) show most values to be between 1.66 and $2.32 \mu$ moles $/ 1$ ( 25 and $35 \mathrm{mg} \%$ ) which is $\overline{\mathrm{x}} \pm \mathrm{SD} .1 .604$ to $2.36 \mu$ moles $/ 1$. $(24.23$ to $35.67 \mathrm{mg} \%)$ of serum. The values obtained for normal by Houchin ${ }^{6}$ was 0.993 to $2.38 \mu$ moles $/ 1$ (15 to $36 \mathrm{mg} \%$ ). Henry ${ }^{5} 1.112$ to. $2.26 \mu$ moles/1 (16.8 to $34.2 \mathrm{mg} \%$ ) and Cantarow Trumper ${ }^{12} 1.32$ to $3.31 \mu$ moles/1 (20 to $50 \mathrm{mg} \%$ ) of serum. The values established in the present study - 1.19 to $2.78 \mu$ moles/1 ( 18 to $42 \mathrm{mg} \%$ ) of serum - closely resemble the reported values suggesting that ethnic factors have no impact on caeruloplasmin levels in adults.

Table 1. Caeruloplasmin pattern in normal Sri Lankans

\begin{tabular}{lcccc}
\hline \multicolumn{2}{c}{ Caeruloplasmin } & & \\
$\mu$ moles $/ 1$ & $\mathrm{mg} \%$ & No. of cases & Males & Females \\
\hline 1.32 & 20 & 7 & 7 & 0 \\
1.65 & 25 & 13 & 13 & 0 \\
1.986 & 30 & 30 & 27 & 3 \\
2.317 & 35 & 26 & 23 & 3 \\
2.648 & 40 & 16 & 13 & 3 \\
2.747 & 41.5 & 2 & 2 & 0 \\
\hline \multicolumn{2}{r}{ Total } & 94 & 85 & 9 \\
\hline
\end{tabular}

\subsection{Pathological specimens}

It is known that in certain diseases and during pregnancy, the caeruloplasmin content varies considerably from normal levels. ${ }^{13}$ Caeruloplasmin levels in pregnancy and in viral hepatitis were found to be elevated and the present findings are in close agreement with the previously published results. The caeruloplasmin levels of pregnant women, given in Table 2 , show values in the range of $2.65 \mu$ moles/1 $(40 \mathrm{mg} \%)$ and above. The arithmetic mean of these cases is $2.93 \pm 0.349 \mu$ moles $/ 1(44.27 \pm 5.27 \mathrm{mg} \%)$ of serum whereas the normal values was shown to be $1.98 \pm 0.378 \mu$ moles $/ 1$ $(29.95 \pm 5.72 \mathrm{mg} \%)$ of serum. These findings are in agreement with those reported earlier. ${ }^{14}$ The pregnancy cases studied had caeruloplasmin levels above the normal mean + 2 SD $2.74 \mu \mathrm{mol} / 1(41.39 \mathrm{mg} \%)$. It is suggested that the raised caeruloplasmin levels in pregnancy reflect an adaptive increase in caeruloplasmin to meet the increasing demand for fetal haemoglobin synthesis. The caeruloplasmin levels of the pathological specimens (Table 3) 
show that in viral hepatitis the caeruloplasmin levels are increased. However, in alcoholic cirrhosis where there is degeneration of the liver cells, the value is low.

Table 2. Caeruloplasmin levels in pregnant mothers

\begin{tabular}{llll}
\hline Age years & $\begin{array}{l}\text { Pregnancy } \\
\text { duration } \\
\text { months }\end{array}$ & $\begin{array}{l}\text { Caeruloplasmin } \\
\mu \text { moles } / 1\end{array}$ & $\begin{array}{c}\text { levels } \\
\mathrm{mg} \%\end{array}$ \\
\hline 31 & $3^{1 / 2}$ & 2.61 & 39.4 \\
22 & 5 & 2.57 & 38.8 \\
- & 5 & 2.87 & 43.3 \\
- & 5 & 3.42 & 51.7 \\
- & $5^{1 / 2}$ & $2.75^{\circ}$ & 41.5 \\
25 & $5^{1 / 2}$ & 3.56 & 53.8 \\
30 & $6^{1 / 2}$ & 2.87 & 43.3 \\
28 & $6^{1 / 2}$ & 3.14 & 47.5 \\
29 & 8 & 2.91 & 43.9 \\
33 & $8^{1 / 2}$ & 2.27 & 34.3 \\
29 & $8^{1 / 2}$ & 3.14 & 47.5 \\
- & 9 & 3.07 & 46.3 \\
\hline
\end{tabular}

The increase in the caeruloplasmin levels in viral hepatitis and the other liver diseases is probably caused by the leak of the enzyme from liver cells due to necrosis. The present study included two cases of Wilson's disease for caeruloplasmin assay, one being $55 \%$ of the lowest limit of normality and the other $28 \%$ (Table 3 ). 


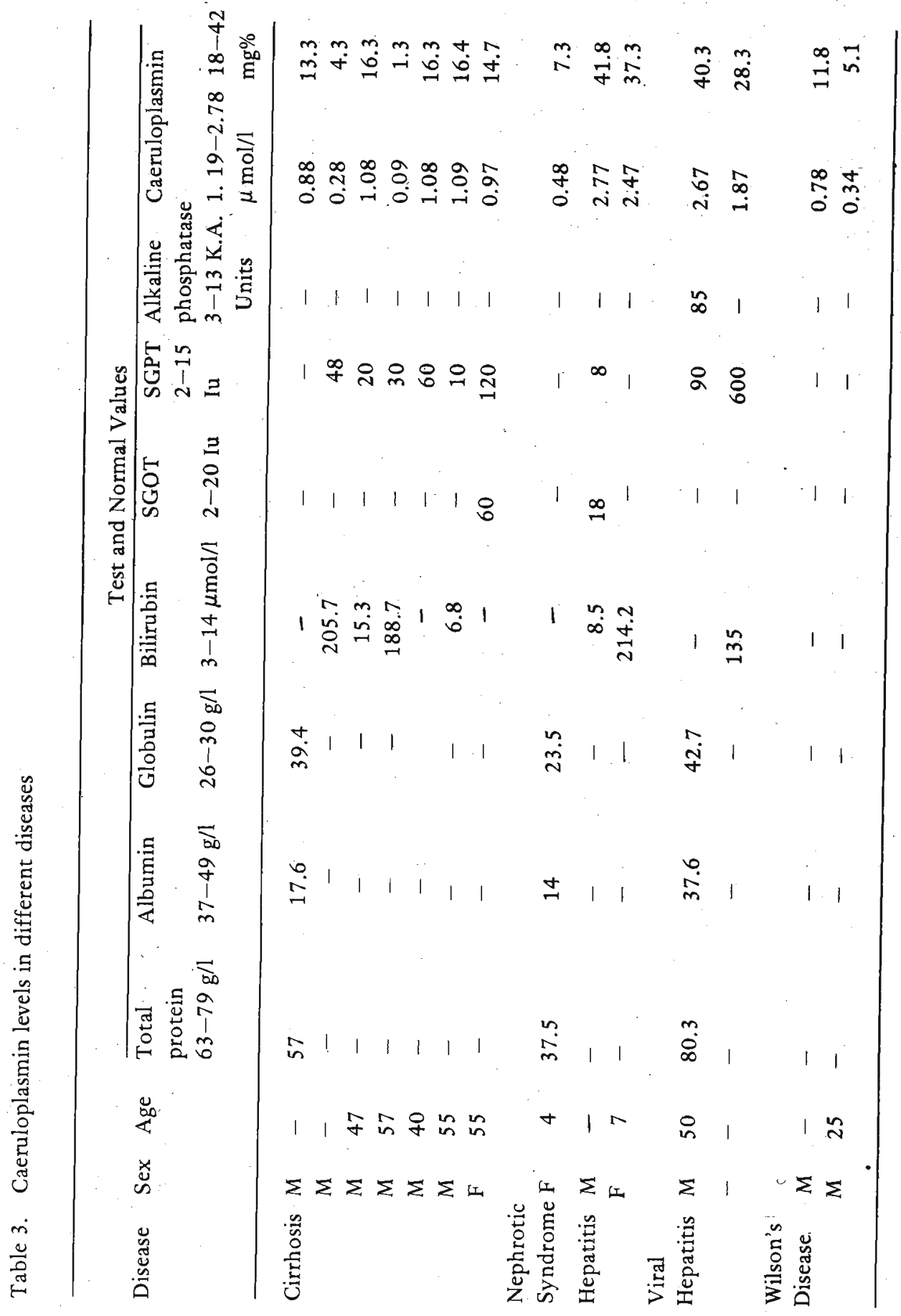




\section{References}

1. CANTAROW, A. \& TRUMPER, T. (1965) Clinical Biocbemistry, 775 p. - N.B. Saunders Company, Philadelphia, London, 262.

2. HENRY, J. B. \& BOWERS, G. N. (1960) JR. An Introduction to Enzymology and serum enzyme assay, American society of clinical patbologists Chicago.

3. HOLEMBERG, G. G. \& LAURELL, C. B. (1948) Acta. Cbem. Scand.,2:550-556.

4. HOLEMBERG, G. G. \& LAURELL, C. B. (1951 c) Scand J. Clin. Lab. Invest, 3 : 103-107.

5. HOUCHIN, O. B. (1958) Clin. Chem., 4:519-523.

6. LATHE, G. H. \& RUThVEN, C. R. J. (1958) J. Clin. Patbol. $11: 155$.

7. SASS-KORTSAK, A. (1965) Adv. Clin. Chem., $8: 35-36$.

8. SCHEINBERG, I. H. \& GITLIN, D. (1952) Science, $116: 484-485$.

9. SCHEINBERG, I. H. \& MORELL,.A. G. (1952) J. Clin. Invest., 36 : 1193-1201.

10. SCHEINBERG, I. H., MORELL, A. G. \& DUBIN, D. (1958) Neurology 8 Suppl. 1 : 44-51.

11. VARLEY, H., GOWENLOCK, A. H. \& BELL, M. Pract. Clin. Biocbem., 1 : 946-948.

12. VAZQUE Z-R \& OLAIABAL;, D. A. (Lab/83:9) Chemistry and quality control for District Laboratories, W. H. O., 38-40.

13. WILDING, P. \& KENNEDY, J. H. (LAB/78.1) Manual of routine methods in clinical chemistry for use in Intermediate Laboratories, W. H. O. 6-8.

14. WOOTTON, I. D. P. (1964) Micro Analysis in medical biocbemistry, 254 P: J \& A Churchill Ltd., 104, Gloucester Place, London W.I. 